\title{
$\begin{array}{lllll}\mathbf{V} & \mathbf{A} & \mathbf{R} & \mathbf{I} & \mathbf{A}\end{array}$
}

\section{ORTHODOXY, SOCIAL MOBILITY AND ECONOMIC PROSPERITY IN SOCIALIST AND POST-SOCIALIST POLAND}

\author{
AGATA ŁADYKOWSKA \\ INSTITUTE OF ARCHAEOLOGY AND ETHNOLOGY, \\ POLISH ACADEMY OF SCIENCES
}

\begin{abstract}
Drawing on the analysis of the life trajectories of second and third generation Orthodox Belarusian farmers born in Poland (aged 50-70), this article discusses the interconnections between religion and economy by looking at the dynamic of the relationship between the socialist modernizing project and a religious identity considered as subaltern. It is argued that by downplaying the significance of religion in the public sphere, socialism made possible social mobility in this group and opened avenues to economic prosperity. The biographies of these farmers indicate a strong correlation between Orthodox identity and aspirations to leave their peasant roots behind and attain a high social status, which has often led to them prospering economically in the post-socialist period.
\end{abstract}

K E Y W O R D S : Orthodox, economic prosperity, Weber, post-socialist capitalism, subaltern, social mobility, socialist modernity

This article concerns the relationship between economy and religion as reflected in the life trajectories of Orthodox Belarusians living in Poland'. Weber's question concerning the relation between economy and religion has a long history in the social sciences, but - to the best of my knowledge - it has rarely been considered in the Orthodox context. I argue that there is a specific historicity of the concepts circulating in the scholarship tackling this issue, which contributes to an avoidance of the Eastern Christian perspective in the analysis. Instead, I propose a research-based theory-building approach enabling a revision of the dominant theoretical models. Such an approach

I This article is based on the material collected during intermittent fieldwork in the Podlasie region in the years 2014-2017, as part of the project financed by NCN, DEC-20II/03/D/HS3/or620. Apart from participant observation, the method comprised of collection of life stories. Within the project on Orthodox economic decision-making, I collected around 30 biographies of Orthodox and Catholic inhabitants of the region. 
has the potential to illuminate both the logic of the relationship between economic prosperity and religion as lived by a specific group in a specific period of time, and the ideologically constructed and conditional nature of the theoretical concepts we rely on. In this article, I ask what implications the salience of Orthodox identity within the Polish post-socialist capitalist economy has for definitions of "economic success". In particular, I would like to open the floor for a discussion about how to conceptualize the category of "economic prosperity" in non-capitalist settings like socialism? What is the logic in which post-socialist capitalisms are embedded?

\section{HIERARCHICAL PLURALISM IN PODLASIE}

Before I attend to the details of my argument, I begin with a story from the field which encapsulates the problem. Mrs. Zoja Stepaniukowa ${ }^{2}$, aged 8I, is an Orthodox believer from the Podlasie region in Poland. I was sitting in her living room, prepared for the initial interview opening my fieldwork in June 20I4. I was able to meet her thanks to the acquaintances I had made earlier amongst Mrs. Stepaniukowa's daughter's Roman Catholic schoolmates. Bearing in mind all the social and scientific implications my regard for those local connections might have, I was very eager to make a good first impression. I had brought some sweets with me, which I had thought would be a nice addition to the tea Mrs. Stepaniukowa would serve. Mrs. Stepaniukowa refused to put them on the table, as if this undermined her image as a hospitable host, and instead served sweets she had baked herself. "They say it is 'second class' Poland here. Well, perhaps not necessarily' (Mówia, że tu Polska 'B'. No, może niekoniecznie taka 'B), she said. As she introduced me to the details of her life, I learned about her childhood in a peasant family. She, her brother, parents, grandparents, and three uncles lived together in a single household in a village located some 30 kilometres from Supraśl. One of her grandmothers was a Roman Catholic. They were all peasants, and were poor but did not go hungry. It was the physical work of farming that was remembered as excruciating, in the same way for all neighbours alike, be they Catholics or Orthodox. Her parents were illiterate and thus "backward" (zacofani), as she put it. But, she said, her parents were also aware of this, so when a school was opened in the village at the beginning of the Second World War everyone saw this development as an opportunity.

However, the ways the school served the community, and specifically the family of Mrs. Stepaniukowa, were complicated. Her older brother, born in I93I, had already completed a year of schooling before the war and, because of this fact, was assigned to a Polish language class; Zoja, born in 1933, had not, and was sent to a Belarusian 
language class. In 1940 the Soviets came, and the language of instruction was changed to Russian. After the war, classes were held in both Russian and Belarusian. When she had completed two years, she was sent off to Supraśl to continue her education in a comprehensive school, in Polish. This was a dramatic change, as she had to learn this language and the Latin alphabet, everything from scratch. Yet, she was very ambitious, as proved by the fact that she was one of only three pupils who completed their fourth year with excellent results and was thus allowed to continue her education at the next level. While in general religion was suppressed by the communist authorities, in the school there was a religion class organized for Catholic children. The Orthodox children, including little Zoja, were welcome to stay quietly in the room and occupy themselves. She thought this was very good, because it helped her to get to know Polish prayers, and taught all the children to have respect for others.

Her parents arranged for her to live in Supraśl. Many of her classmates were from the surrounding villages. Some of them walked io kilometres every day, through swampy meadows and forests. The parents of others rented a room in exchange for food. The children had no shoes, and their school bags were made by hand from potato bags. But a point Mrs. Stepaniukowa made explicitly was that education was free, provided by the socialist state. Parents were obliged to contribute by providing food, but, as villagers, they did not see this as a problem. Later, Zoja finished a vocational secondary school as a seamstress, and still later she trained in an administrative school in Białystok - the central city of the region. As a result, she became an accountant, and this remained Mrs. Stepaniukowa's profession until retirement. During the early post-war years, the educational system underwent a series of structural reforms, which never discouraged her in her pursuits of a better tomorrow.

Thus, after the Second World War, Zoja, her brother, the seven sons of her widowed aunt and all her cousins were among the first generation of the local Belarusian population to receive formal education. All of them left their villages and their peasant families to become professionally trained soldiers, Orthodox priests, mechanics, carpenters, seamstresses, gardeners, state office workers, waitresses, foresters, shop assistants or took on other trade related positions while working and living in urban centres. Zoja has stayed in Supraśl to this today, although her brother emigrated to Warsaw and so have her children. They all appear to be doing very well, pursuing satisfying careers in the capital of Poland and visiting their grandmother from time to time.

While we were sitting and talking, the sounds of a popular Catholic song suddenly filled the air. I looked at Mrs. Stepaniukowa, a devout Orthodox believer, to see if this made any impression at all on her, but she just smiled ruefully saying that: "This is normal here." Nonetheless, during my stay in the field I could not help but detect an ongoing symbolic tension. Supraśl is a popular tourist destination. The showpiece here is the Orthodox (once Uniate) Monastery of the Annunciation, located on the outskirts of the town. Supraśl, and other picturesque settlements in the Podlasie region, 
like Królowy Most, Sokółka and Tykocin, have functioned as pieces of scenery in several popular Polish television series and in this way have become embedded in the collective imagination as an idyllic land of cultural harmony. At the same time, in 20I4, the aural landscape of this small, pastoral semi-urban settlement seems to be dominated by signs of the Catholic religion. One can hardly hear the bells from the monastery, but is constantly confronted with loud Catholic music, emitted three times a day from one of the two Roman Catholic churches in Supraśl. I was accompanied in the field by my mother, a middle-aged woman brought up in a small city in central Poland, and she found this "innocent" musical practice very enjoyable, affording her an opportunity of a sentimental return to her childhood. Maryjo, Królowo Polski (Mary, the Queen of Poland) or Boże, coś Polskę (God Save Poland) are some of the most popular Polish religious songs, and are imprinted in the minds of virtually all Poles who grew up in socialist Poland with the feeling that the church provides them with a sense of belonging to a national community. In provincial, multiethnic regions, however, these religious songs translate into ethnic anthems, which have a powerful effect on the symbolic balance between multiple local identities.

That there is a real tension here is highlighted by another fact I registered in the field. When I entered the premises of the local municipality - with a Catholic cross on visible display - to introduce myself and explain the aim of my visit - I received a discouraging answer from the local authorities, who suggested that I had picked the wrong place to study Orthodoxy: "There are no Orthodox in Supraśl. Maybe io\%." This statement refuses the Orthodox minority any significance and, in fact, shows that local religious diversity is not acknowledged. Moreover, the denial of the existence of minorities is supported by the two most serious institutional players: the Catholic Church and the city administration.

This phenomenon is described for other multicultural regions of Poland as "hierarchical pluralism" (Pasieka 20I5), a term denoting a configuration of social relations which allows plurality, while at the same time establishing one (ethnic/religious) group as dominant and norm-defining. In other words, expressions of pluralism do not only hide real power relations, they also become a way for the majority to exercise symbolic power. Pasieka argues that the foundation of hierarchical pluralism is the normativity of the idea of the "Pole-Catholic", which is promoted and reinforced by different state and Church policies, and which is referred to and deeply internalized by minority groups.

In Podlasie, the question of identity and the majority/minority dynamic is complex, and there is no consensus among the academic community. Relevant scholarship concerned with questions of difference in this borderland region pays attention to configurations of religion, ethnicity, language, culture and class (e.g. Babiński 1997, Sadowski 1995, Smulkowa 2002, Golachowska 2012, Straczuk 2006, Engelking 1995, 20I2). It is interesting that the same literature has been called upon by the two 
anonymous reviewers of this text, but led them both to competing conclusions on the nature of the constellation of these aspects. On the one hand, since these studies often concern the uneven distribution of prestige attributed to these selected aspects of identity, some of these authors claim that the links between religious and ethnic identities are not obvious and firmly defined, but rather that they are labile, dependent on historical and social circumstances. The role of religion as the trigger of social mobility is thus occluded. However, others stress that it is the characteristics of Orthodox practice and the specific cultural and historical context of this area that result in religious denomination being so strongly connected to ethnicity, class (peasantness) and political affiliation.

While not denying the significance of these insights, I believe that the employment of the concept of hierarchical pluralism allows us to turn the analytical gaze towards emic experiences and manifestations of symbolic violence as a marker of difference. I argue that the conditions brought about by the socialist modernizing project opened a space for social mobility among the suppressed Belarusian minority, many of whom attained high social status because they were Orthodox ${ }^{3}$. Their subaltern position is a result of both formal and informal modes of local politics which have favoured the Roman Catholic majority before, under and after communism. While I do not attend here to the details of Orthodox practice, I do inquire into how people conceptualize the aspirations which have shaped their life trajectories, including their economic pursuits, and where they draw lines of potential cultural difference. As I show further, my informants made a move forward on the social ladder in terms of comparison with their Polish Catholic counterparts, and at the expense of their religious identity, which nevertheless remains at the centre of their economic decision-making. Therefore, in the analysis I render religion a contributing, not a "genetic", or determinant, factor of long-running patterns of political and economic development. I thus place religion within the context of wider institutional changes and power relationships, and their consequences for self-understanding.

\section{BELARUSIANS ORIENTALIZED}

The people described in this article are a local population inhabiting the peripheral region of Podlasie and self-identifying as ethnic Belarusians. Their forefathers became Polish citizens when these territories were incorporated into the Polish state in I92I, after the resettling of borders with the Soviet Union through the Riga Treaty, or, in their own words, "when the Polish administration came here." As a minority group,

3 While a similar observation has been made earlier (e.g. Kłoskowska 1996, 204-233), in this article I look at the distinctive ways whereby religion played a part in this process. 
their everyday life has been shaped by two complementary factors: the conditions of hierarchical pluralism (Pasieka 20I5), with Polish-Catholic identity seen as "normal", and the socialist project of class emancipation through, among other things, policies of atheism. These two factors seem to be at the root of people's life decisions concerning their choices of careers.

Within public discourse, the Orthodox orientation of my informants (and their Belarusianess) has been crudely orientalized. Thus, the popular derogatory designation for a member of this group, kacap, denotes a range of attributes held in contempt in the Polish public sphere: sympathy for Moscow, a leftist (or - during socialism communist) orientation, disloyalty towards "Polish values" or acting to the detriment of the Polish state, passivity in the face of adversity, a submissive attitude towards the authorities (Gołubowska 2013), peasant origins, helplessness, lack of education, crudeness, uncouthness, stupidity and a feeling of being treated unjustly (Giedroyć 2013, quoted in Gołubowska 2013, 259-260). Although everyday interactions make such opinions more benign, this does not preclude such "non-modern", orientalized images being internalized by the Orthodox themselves. The ancestors of this group were described by one of my interlocutors as "imprisoned in an alternativeless peasant way of life", but their life trajectories, forged under socialism, were shaped by conscious decisions directed at abandoning their Belarusian identity in all its possible expressions and "becoming Polish". This process has generated a high rate of upward social mobility in this population, which in the generation of 50-70 year-olds translated into the aspiration to achieve a higher education (often accomplished beyond the Podlasie region), leftist sympathies, a tendency to secular attitudes, an abandonment of work in agriculture, gravitating towards an urban lifestyle (and place of settlement) and a choice of careers they associated with Polishness (e.g. white collar jobs, clerical positions in state administration) or considered prestigious, but that under socialism were possible to achieve only through membership in the party structures. All these life decisions turned out to be crucial for accumulating social capital during socialism, which they have further attempted to convert into economic capital after 1989. Such has been the foundation of the economic status and social position they have attained by 2014 .

Initially, the project of which this article is one outcome was designed to explore the links between economy and religion in a more general way, and did not specifically focus on the legacies of socialism. Drawing inspiration from a number of other studies that have taken a similar point of departure (e.g. Köllner 20I2; Kormina 20IO), it aimed at investigating current economic practices connected with pilgrimages, as the Monastery of Annunciation in Supraśl is a centre of Orthodox pilgrimage. I expected to see some capitalist-oriented activity: proliferating guesthouses, restaurants and all sorts of services provided for guests, that - I speculated - might cater for their religious and other needs. My first weeks of fieldwork brought virtually no results, as the market 
of services connected with hosting pilgrims is either non-existent or run exclusively by monks. This observation, for which it is hard to provide a simple explanation, prompted me to combine both diachronic and synchronic perspectives. It turned out that the areas of economic activity capable of mobilizing the Orthodox community had already been carefully chosen in the distant years of early socialism. My initial assumption, that economic success needs to be expressed in financial terms and in the conditions of formal capitalism, therefore turned out to be erroneous. I had to adapt my project to consider longer historical trajectories, because the dynamic of the relationship between religious identity and economic decision-making in this particular case can only be seen over the course of entire lives, if not indeed over two or three generations.

Thus, the research into the salience of Orthodox identity within the Polish post-socialist capitalist economy had to be modified in the face of empirical findings which challenged the theoretical framework that had underpinned the design of my project. The relevant social theory makes normative assumptions emphasizing the ("organic") link between modernity, individualism and secularity. In so doing, it draws on Western culturalist assumptions not sufficiently commensurable for meaningful comparisons to be made with the Orthodox, postsocialist context. The exposure of these ethnocentric premises is thus an additional benefit of the fieldwork. Deeply ingrained biases concern the definition of religion, the relationship between religion and culture and the definition of material success. These all become clearer by incorporating a temporal dimension into this research.

In line with the scholarship on post-socialism attempting to develop methodologies to structure continuity and change, I look for an analytical framework able to account for the shift in the social significance of various concepts intrinsic to the socialist and Western incarnations of modernity by looking at the dynamics of social mobility. The Belarusians under study experience their Orthodoxy as a "phantom religion" existing alongside their self-avowed secularity; their Orthodox identity thus constantly influences them with regard to how to place themselves within a wider, Polish-Catholic society. How, then, are we to explain the significance and the role of religion in these processes? The explanation of this question must start with the specificities of the Orthodox conceptualization of religion, because the practical responses they inspire may generate an impression that religious identity is non-existent or irrelevant in this process.

\section{SOME INADVERTENT LEGACIES OF MAX WEBER}

Eastern Christianity as an area of study remains under- and misrepresented in the social scientific scholarship (Hann and Goltz 20IO; Hann 20II; Lubańska and 
Ładykowska 2013), and its interplay with different fields of power, including that of economy, remains understudied; a lacuna in scholarship which has serious implications for anthropology, and for social theory more broadly (Hann 20II; 20I2). This situation owes much to Max Weber. Weber's framework underlined the economic ethic (Wirtschaftsethik) of Protestantism as key to the genesis of modernity, secularity and European exceptionalism, but an inadvertent result of this line of thought is the continued emphasis on Protestantism which has dominated anthropological reflection on religion ever since. The exposure of the "Christian bias" embedded in the deep structures of anthropological theory (Cannell 2005; Robbins 2007) brought little amendment to this imbalance, since the scholarship produced in the relatively new current of "anthropology of Christianity" continues to be distorted by a Protestant bias (Cannell 2006; cf. Hann 2007). The result is the general neglect of anthropology for other branches of Christianity (Hann and Goltz 20IO; Hann 20II; 20I2; Zowczak 2000; Lubańska and Ładykowska 2013), as under the heading of the "anthropology of Christianity" one finds almost exclusively ethnographies of Protestant or Pentecostal movements from the postcolonial world (e.g. Cannell 2005; 2006; Robbins 2003a; 2003b; 2004; 2007; Keane 2007; Tomlinson 2006; Engelke 2006; Tomlinson and Engelke 2006). Eastern Christianity is thus excluded from many levels of anthropological reflection, including deep structures of anthropological theorizing.

At the same time, another solid anthropological/theoretical meta-representation, also owed to Weber, is the link between material/financial success and interiorized belief. The cornerstone of Weber's concept of work ethic (200I) is Luther's notion of work as a vocation. Weber, thus, argued that the emergence and spread of capitalism relied on mobilizing Protestantism's stress on hard work and productivity. The link between a Protestant ethic and economic success has been pursued by numerous authors since Weber to describe the distinctive evangelical spirit of American capitalism and establish a firm representation of "prosperity theology" (a.k.a. the health and wealth gospel), linking faith with financial success. Outside of the U.S. context, prosperity theology has been linked to the globalization of charismatic Christianity (Coleman 2000), and described as a highly "portable", transnational entity that is easily adapted to new social contexts (Bielo 2007). This conceptualization inhibits the possibility of the inclusion of other religious traditions into the agenda set by Weber. In effect, with a few notable exceptions, such as Köllner (e.g. 20I2), studies addressing the "Weber question" in the Orthodox context are almost non-existent.

Another corollary of Weber's influence is a widespread bias in the definition of religion, based on a Christian (or, more precisely, a Protestant/Calvinist) idiom (Asad 1997; Cannell 2005). Most often, anthropological scholarship ideologically privileges a notion of religion that prioritizes personal, private faith over collective, public practice. This means an inherent discrimination toward religious traditions in which public manifestations of religion are privileged, as is the case, amongst others, in Eastern 
Orthodox Christianity. Historical-sociological studies suggest that the patterns of the historical development of Orthodox societies have shaped an understanding of religion as a core constitutive element of ethnic and national identity (Agadjanian and Roudometof 2005; Werth 1996), heavily influenced by the territorial spread of faith. As a result, Orthodoxy remains a matter of birthright rather than personal belief, (and therefore the globalization paradigm, held responsible for the spread of Charismatic Christianity, produces remarkably different effects in these societies), and can be seen as a source of a collective identity even without belief in any form of divinity (Ghodsee 2009). Weber's influence remains fundamental in the way it has shaped anthropological common sense, but equally his thought forms a methodological and theoretical obstacle to the anthropological study of Eastern Christianity. This article is an attempt to circumvent these deadlocks and offer an innovative perspective by investigating non-capitalist forms of accumulating wealth, signalling unexpected ways in which the religious factor plays out in the economic sphere and at the same time being inclusive of Eastern Christianity.

\section{CAREERS ENCOURAGED BY THE SOCIALIST STATE}

Mr. Bobryk was a retired, elegant man, described to me by his son as a successful entrepreneur running a modern hostel in the centre of one of the urban settlements in Podlasie. The son described himself as an atheist, but suggested that his father was Orthodox and, therefore, a "potentially interesting person to talk to." Mr. Bobryk was born in 1947 into a peasant Orthodox and Belarusian family in a tiny village in the region. During his secondary school years in an urban settlement, he discovered the prestige accorded to the profession of a geodesist when geodetic surveyors visited the village of his origin and demonstrated enormous power over the locals by re-measuring the land allocated to each household. This prompted him to pursue a university education at the geodetic department of the local university in Białystok, an education which, he imagined, would grant him a similar status and free him from the fate of being a farmer. This move proved profitable. He was very soon allocated a prestigious job, and then an apartment. He noticed that formal participation in the communist party structures brought further benefits. Thanks to this, he was easily able to attain goods unavailable to others. He and the head of the police were the first to be allocated apartments in the first block of flats built in his city. He was also the first to receive a telephone connection, with the notable number " $\mathrm{I}$ " underlining the significance of this development.

Mr. Bobryk married a Catholic woman. They married in a Catholic church, in a remote, homogeneously Catholic region of Poland in order to avoid gossip and provoking zacietrzewienie - heated attitudes and fights. This, in his view, had no 
important effects on their family life, because in essence he "is an atheist." This meant in practice that Mr. Bobryk visits the Orthodox church "on occasions, like Christmas or Easter, or when someone dies or gets married", which serves to prove his attachment to his Orthodox community and identity rather than to its ritual life. For years, he and his wife received the visits of both Catholic and Orthodox priests during koleqdaa traditional round of visits to parishioners' homes, usually connected with the collection of donations. The soliciting of donations, along with the fact that religious institutions do not pay taxes and behave "as if the law did not concern them", filled Mr. Bobryk with contempt for both Orthodox and Catholic clergy alike. His career developed beyond his expectations: he was promoted within the state geodetic office and often sent for business trips abroad. Trips abroad were a tremendously attractive activity for the citizens of a socialist country, and almost impossible to arrange on a private basis without bureaucratic hassle. These trips proved in his eyes that he was a man of success, and they are what he misses most today.

This mixture of contempt and fascination for Orthodox traditions, that at once provide the bonds to home and an impediment in striving for a better future, is also, though to a lesser extent, visible in the account of Mr. Mironowicz. Mr. Mironowicz is one of the wealthiest cattle breeders in this part of Poland, a full-scale entrepreneur whose capital was accumulated long before 1989. When I asked him whether he feels Belarusian, he answered: "Today, this is a less complicated issue than earlier in life. As a young man, I was doing everything to become a Pole. But this did not work". He was born in the I940s, to a peasant, Orthodox Belarusian family. They lived in a village "beyond the forests, the periphery of peripheries", with 40 households, $4 \mathrm{~km}$ from the closest train station. An "enclave in the middle of the forest, with extremely primitive life conditions, but this was normal then." His first job, undertaken at the age of 4 , was cattle grazing. From then on he has continued to enjoy nature and the presence of animals. When he was a schoolboy - attending school in another remote village, travelling each day through the snow and mud with no shoes - he encountered an officer from the education office. The officer visited the school to perform tests on pupils, probing their capabilities, potentialities and knowledge, and then indicated their possible career paths. Unexpectedly for himself, young Mironowicz heard: "You can do anything you like in life. You are a person of many talents, you can engage in whatever you dream of." Today, when he looks retrospectively at his biography, he understands that this was the decisive moment: the first time when he was presented with other life opportunities, and recognized them as such.

Mr. Mironowicz understands also that in his family his was the very first generation with a range of possibilities to explore in life, because his ancestors were "imprisoned in an alternativeless kind of life". So young Mr. Mironowicz dreamt of a career as a teacher. He moved to an urban settlement where a pedagogical college was located. As a Belarusian, he was allocated to a class in the Belarusian language. The school's 
strategic - but not articulated outwardly - aim was to educate professional teachers for the Belarusian minority in the region. This goal was attained by means of allocating as pupils Belarusian locals, who would not therefore be learning an additional foreign language. When young Mironowicz was about to pass his final exams he discovered that the lack of a course in a foreign language was a deliberate move: it inhibited his eligibility for admission to the university level education (where it was a requirement), of which he had dreamt, and in this way ensured that the college alumni would not leave for other regions, but instead stay among the local population. This, according to Mr. Mironowicz's retrospective attempts to make sense of his biography, was a political aim of the Polish state to handle ethnic minorities and keep them under control in specific regions. He learned the basics of Russian and passed his exam. Then young Mironowicz was conscripted into the army and sent to Warsaw, where he was again confronted with people from different walks of life.

During these years, he decided on a career as a professional farmer. He was eager to have a university education, but amongst all the possible disciplines he saw cattle breeding as the only one he would be capable of studying, as it was something that he liked and knew. When he occasionally visited his parents in the village, he already felt like someone with a different background than his family and peers, and there was no real communication between them. His schoolmates could not believe that something like cattle breeding, an activity known to any child in the village, could become a separate scientific discipline at a university. They treated his words with a mixture of respect and disbelief. At the same time, his colleagues in Warsaw also had reservations. The first question he was usually asked concerned his place of birth. When he once replied "Podlasie", his interlocutor replied with laughter: "You don't have to tell me that, I can hear it in your accent. Which part exactly?" This made Mr. Mironowicz reflect on the way he spoke: his accent and pronunciation revealed his Eastern roots, his selection of words and expressions revealed his peasant origin. He decided to make an additional effort and forced himself to "speak like a normal Pole." Feeling lonely and othered in Warsaw, he frequently visited an Orthodox parish, but what he found there was not really a local community, just a group of Orthodox people who happened to be in Warsaw, far from their homes scattered across remote peripheral regions. Longing for some brotherly spirit, he visited a Ukrainian organization, but did not feel at home there. A university colleague, also an Orthodox Belarusian, once told him: "Wasia, you will never become a part of the Polish intelligentsia. Don't bother yourself with it." He was clearly determined to attain this status, but at the same time felt that what he perceived as barriers - discovered so late in life - such as his speech, his religion, his lack of manners and his inability to talk about various topics in a sophisticated way, are extremely difficult to erase.

Socialism eliminated the first barrier by removing religion from the public sphere; but there were other factors that he was unable to combat on his own. He decided to 
go back to Podlasie, where he met his future wife, an Orthodox Belarusian woman, with whom he genuinely fell in love. With his university education, he entered the communist party structure in the village and was immediately allocated one of the best jobs in the area: that of the director of a cooperative for maintaining agricultural machinery. Soon, his father-in-law decided to sell his land to the state and start a socialist-entrepreneurial farming activity, a move which enabled him to build a professional full-scale cowshed. Over the years, this activity has developed: thanks to Mr. Mironowicz's connections, they were able to obtain low-percent loans from the state. In the late 1980s, when the socialist system was about to fall, Mr. Mironowicz intuitively expected inflation and made a gigantic effort to pay off the loans. This move saved him the enormous financial troubles which would inevitably have followed in a few months after the fall of the system. He instead invested a small amount of capital into a herd of calves, sold for next to nothing by the previous state farm that was now in a state of collapse. Soon his new business developed, and during the period 2000-20I5 Mr. Mironowicz's capitalist intuition allowed him to avoid risks and to multiply his capital by thousands.

I chose these two accounts, because they are indicative of different aspects of one and the same thing: of how an entangled identity comprising class, ethnicity and religion evolved under conditions established by the policies of socialism and hierarchical pluralism. By removing the first barrier, i.e. downplaying the significance of religion, it allowed these (Orthodox) Belarusians to compete with (Catholic) Poles for lucrative positions. These two stories are complementary in the way they illuminate the intentions of both these men. The normativity of the idea of a "Pole-Catholic", internalized by these people, in complicated ways motivates decisions that bring changes to the configurations of different aspects of their identity. Mr. Bobryk benefited from the socialist policies of atheism and of class emancipation through education in his pursuit for a better life, but this does not entail a wholesale rejection of Orthodoxy. That these pursuits are a conscious choice of the abandonment of one aspect of identity in favour of another is visible in the biography of Mr. Mironowicz. He presents his social mobility decisions as an attempt to become "a Pole", an attempt that failed, as he remarked bitterly. The line of difference that he draws between himself and his Polish counterparts is one of class, but seeking to change it involves a modification of language, education, status and intellectual horizon. In his attempts at identifying the meanings of different kinds of bonds he has maintained - with fellows from his home region, with Poles from central Poland or with local institutions - he is confronted with a whole range of aspects of varying political valence, which nevertheless have an impact on his ultimate self-identification as an Orthodox Belarusian. In effect, the status and success that these two men have attained has been stimulated by their continuous reflection on their identity as confronted with the construction of the idea of a Pole. 


\section{CONCLUSIONS}

I propose here to look at the economic choices of Belarusian farmers in Poland as inspired by their subaltern position, due to the policies favouring another religious denomination, and by the opportunities opened up by socialist policies downplaying the significance of religious identity. When religion is seen as a "phantom identity" which informs future life decisions, the cases presented show clear affinities between an explicit religious identity and one's economic trajectory, and may thus add another dimension to the existing body of literature and theory within the anthropology of Christianity.

At the same time, I believe these examples illustrate the complex local legacies at play. The socialist legacy of suppressing religion, viewed as an antithesis of modern identity, was particularly well absorbed by members of the Orthodox community. Paradoxically, the success of this legacy needs to be seen against the backdrop of the idea of "Pole-Catholic". Class inequalities in pre-war Poland determined specific modes of belonging, but socialist modernity reshuffled not only the class affiliation but the entire allocation of different forms of social and economic capital altogether. Socialist policies thus softened many barriers and restrained hierarchies inhibiting these Belarusians from integrating into the (Polish) society. Moderating the meaning of religious identities in the public forum and promoting a specific perspective on what it means to be modern stimulated upward social mobility and contributed to the accumulation of social and economic capital. These legacies have continuously marked the patterns of local relationships in the region, bringing surprising reconfigurations between class, religion and national identities.

Erroneous was the initial assumption of my project that economic success needs to be expressed in financial terms and in the conditions of formal capitalism. Biographies of my interlocutors show clear patterns that allow for some more general conclusions. But I could not see these patterns until I met Mr. Mironowicz. His biography thrown light on all the other biographies of my Orthodox informants. It helped me to conceptualize aspirations as a mode of social mobility, signalling the status at the point of departure, the projected future status and the means to attain it. Mr. Mironowicz's life story allowed me to structure the life events of others in economic terms and see them against the backdrop of accompanying political - formal and informal - processes.

In this way, this article hopes to show how simplistic are widespread explanations emphasizing the absence in the Orthodox tradition of a Protestant ethic based on an interiorized asceticism, and, by this token, Orthodoxy's failure to develop the combination of political, legal, and economic conditions that allow for a breakthrough to an increasingly secular modernity as in the West. Instead, I look at the distinctive ways in which Orthodoxy locally patterned, but not necessarily determined, conceptions concerning the relationship between the self and the wealth. 


\section{BIBLIOGRAPHY}

A gad ja n i a n A. and R o ud o m e t of V. 2005. Introduction: Eastern Orthodoxy in a global age preliminary considerations. In V. Roudometof, A. Agadjanian and J. Pankhurs (eds.), Eastern Orthodoxy in a Global Age: Tradition Faces the Twenty-First Century. Walnut Creek, Lanham, New York, Toronto, Oxford: Altamira Press, I-26.

A s a d T. 1997. Genealogies of Religion. Baltimore: John Hopkins University Press.

B a b i ń s k i G. 1997. Pogranicze polsko-ukrainskie. Etniczność, zróżnicowanie religijne, tożsamość. Kraków: Nomos.

B i e lo J. S. 2007. 'The Mind of Christ': financial success, born-again personhood, and the anthropology of Christianity. Ethnos 72 (3), 315-338.

C a n n ell F. 2005. The Christianity of anthropology. Journal of the Royal Anthropological Institute II (2), $335-356$.

C a n n ell F. 2006. Introduction. The anthropology of Christianity. In F. Cannell (ed.), The Anthropology of Christianity. Durham and London: Duke University Press, I-49.

Cole m a n S. 200o. The Globalisation of Charismatic Christianity: Spreading the Gospel of Prosperity. Cambridge: Cambridge University Press.

En g el ke M. 2006. Clarity and charisma: on the uses of ambiguity in ritual life. In M. Engelke, and M. Tomlinson (eds.), The Limits of Meaning. Oxford: Berghahn, 63-83.

Engelking A. 1995. "Jak katolik to Polak". Co to znaczy? Wstępne wnioski z badań terenowych na Białorusi. In A. Sadowski (ed.), Wschodnie pogranicze w perspektywie socjologicznej. Białystok: Fundacja Ekonomistów Środowiska i Zasobów Naturalnych, 138-I46.

Engelking A. 20I2. Kotchoźnicy. Antropologiczne studium tożsamości wsi biatoruskiej przetomu XX i XXI wieku. Toruń: Wydawnictwo Naukowe Uniwersytetu Mikołaja Kopernika.

G h o d s e e K. 2009. Symphonic secularism: Eastern Orthodoxy, ethnic identity and religious freedoms in contemporary Bulgaria. Anthropology of East Europe Review 27 (2), 227-252.

G o l a ch ow s k a E. 20I2. Jak mówić do Pana Boga? Wielojęzyczność katolików na Biatorusi na przetomie XX i XX wieku. Warszawa: Agade.

G o ł u b o w s k a U. 20I3. Tożsamość Polaków wyznania prawosławnego. Biatoruskie Zeszyty Historyczne 40, 257-269.

Han n C. 2007. The Anthropology of Christianity per se. Archives européennes de sociologie 48 (3), 383-4IO.

H a n n C. 20II. Eastern Christianity and western social theory. Erfurter Vorträge zur Kulturgeschichte des Orthodoxen Christentums Io, 5-32.

H a n n C. 2012. Personhood, Christianity, modernity. Anthropology of This Century 3 , http://aotcpress.com/articles/personhood-christianity-modernity/

$\mathrm{H}$ a n n C. and G o l t z H. 2oro. Introduction: the other Christianity? In C. Hann and H. Goltz (eds.), Eastern Christians in Anthropological Perspective. Berkeley, Los Angeles, London: University of California Press, I-29.

Ke a n e W. 2007. Christian Moderns: Freedom and Fetish in the Mission Encounter. Berkeley: University of California Press.

Kło s k ow sk a A. 1996. Kultury narodowe u korzeni. Warszawa: PWN.

Ko r m i n a J. 20IO. Avtobusniki: Russian Orthodox pilgrims longing for authenticity. In C. Hann and H. Goltz (eds.), Eastern Christians in Anthropological Perspective. Berkeley, Los Angeles, London: University of California Press, 267-286.

Kölln e r T. 20I2. Practising Without Belonging? Entrepreneurship, Morality, and Religion in Contemporary Russia. Berlin: Lit-Verlag. 
L ub á sk a M. and Ładykowska A. 20I3. Prawosławie - „chrześcijaństwo peryferyjne”? O teologicznych uwikłaniach teorii antropologicznej i stronniczości perspektyw poznawczych antropologii chrześcijaństwa. Lud 97, 195-219.

Pa s i e k a A. 2015. Hierarchy and Pluralism: Living Religious Difference in Catholic Poland. Houndmills, Basingstoke, Hampshire: Palgrave \& Macmillan.

Robbins J. 2003a. What is a Christian? Notes toward an anthropology of Christianity. Religion 33, I9I-99.

R obbin s J. 2003b. On the paradoxes of global Pentecostalism and the perils of continuity thinking. Religion 33, 22I-3I.

R o b b i n s J. 2004. Becoming Sinners: Christianity and Moral Torment in a Papua New Guinea Society. Berkeley: University of California Press.

Robbin s J. 2007. Continuity thinking and the problem of Christian culture: belief, time, and the anthropology of Christianity. Current Anthropology 48 (I), 5-38.

S a d ow sk i A. 1995. Pogranicze polsko-biatoruskie. Tożsamość mieszkańców. Białystok: Trans Humana.

$S \mathrm{t}$ r a c z u k J. 2006. Cmentarz i stót. Pogranicze prawostawno-katolickie w Polsce i na Biatorusi. Wrocław: Wydawnictwo Uniwersytetu Wrocławskiego.

S m ułk ow a E. 2002. Biatoruś i pogranicza: studia o języku i spoteczeństwie. Warszawa: Wydawnictwo Uniwersytetu Warszawskiego.

Tomlins on M. 2006. The limits of meaning in Fijian Methodist sermons. In M. Engelke and M. Tomlinson (eds.), The Limits of Meaning. Oxford: Berghahn, I29-I46.

To m lin s o n M. and Eng el ke M. (eds.) 2006. The Limits of Meaning. Oxford: Berghahn.

We b e r M. 200I [1905]. The Protestant Ethic and the Spirit of Capitalism. London \& Chicago: Roxbury Publishing Company.

We r t h P. 1996. Subjects for Empire: Orthodox Mission and Imperial Governance in the Volga-Kama Region, I825-I88I. PhD Dissertation, University of Michigan.

Z ow c zak M. 2000. Biblia ludowa, Wrocław: Funna.

\section{Author's contact:}

Agata Ładykowska PhD

Institute of Archaeology and Ethnology PAN

ORCID: oooo-ooor-5263-3756

Email: agata.ladykowska@gmail.com

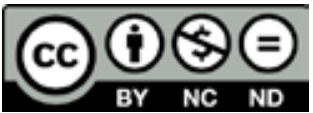

